\title{
Gravity basement of the Guinsaugon landslide along the Philippine Fault Zone
}

\author{
Masahiko Makino $^{1}$, Allan A. Mandanas ${ }^{2}$, and Sandra G. Catane ${ }^{2}$ \\ ${ }^{1}$ Geological Survey of Japan, AIST, Tsukuba, Japan \\ ${ }^{2}$ National Institute of Geological Sciences, University of the Philippines, Diliman, Quezon City, Philippines
}

(Received March 9, 2007; Revised July 23, 2007; Accepted September 6, 2007; Online published October 19, 2007)

\begin{abstract}
A gravity survey was conducted in Guinsaugon, St. Bernard, Southern Leyte, Philippines, to determine the subsurface structure of the Leyte segment of the Philippine Fault Zone (PFZ), where a massive landslide killed 1119 villagers on 17 February 2006. The landslide started on top of a 780-m-high ridge linked with the PFZ. The build-up of pore pressure in the slope due to saturation and possible earthquake-triggered ground shaking along the PFZ, may have initiated the landslide. A two-dimensional structure using homogeneous density models was applied to interpret the gravity anomalies in the Guinsaugon landslide. The most suitable model depicts a deep, narrow graben filled with low-density sediments. The graben is $1.5 \mathrm{~km}$ wide and $2 \mathrm{~km}$ deep and has a density contrast of $-0.4 \mathrm{~g} / \mathrm{cm}^{3}$. The western boundary of the graben is steep and coincides with the terminus (southern) Leyte segment of the PFZ. The existence of a deep-seated seismically active fault at the foot of the steep slopes and the soft sediments in the narrow graben are important factors in understanding the trigger and failure mechanisms of the landslide and in the assessment of hazards and risks due to landslides and earthquakes. Key words: Gravity, landslide, Guinsaugon, Philippine Fault Zone, earthquake.
\end{abstract}

\section{Introduction}

The gravity method has been proven to be an effective tool for delineating subsurface structures in volcanic calderas (Yokoyama and Ohkawa, 1986; Komazawa, 1995), sedimentary basins (Litinsky, 1989), and faults (Ferguson et al., 1988; Makino, 1997; Lukandu et al., 2003). Gravity data that are obtained with a better control on the location of the gravity stations using the Global Positioning System (GPS) provide a better resolution of the boundaries, shape, and mass contrast of subsurface structures (Makino and Endo, 1999; Williams et al., 2006). For example, a gravity study around the zone in Kobe, Japan, most severely damaged in the 1995 Hyougoken-Nambu earthquake depicted steep Bouguer anomaly gradients that were interpreted to be concealed faults within a coastal plain (Endo et al., 1996). The northern boundary of the severely damaged zone was found to coincide with the largest step of the gravity basement structure. In the case of the 1997 Hariharagawa debris flow at Izumi, Kagoshima Prefecture, Japan, the crown area of the landslide is located at the boundary of high-gravity anomalies, which in turn corresponds to the boundary wall of the concealed intrusive dyke (Makino and Endo, 1999).

On 17 February 2006, a catastrophic rockslide-debris avalanche occurred in Guinsaugon, St. Bernard, Southern Leyte, Philippines (Fig. 1). It is the largest and most devastating landslide in the Philippines to date. St. Bernard lies along the Leyte segment of the active Philippine Fault Zone (PFZ). The PFZ has generated large earthquakes, including the $M_{\mathrm{S}}=7.8$ Luzon earthquake in 1990 along the

Copyright (c) The Society of Geomagnetism and Earth, Planetary and Space Sciences (SGEPSS); The Seismological Society of Japan; The Volcanological Society of Japan; The Geodetic Society of Japan; The Japanese Society for Planetary Sciences; TERRAPUB
Digdig fault in northern Luzon, the 17th and 18th century $M=7$ or larger earthquakes along the Guinyangan fault in Quezon province (Besana and Ando, 2005), and the more recent $M_{\mathrm{s}}=6.2$ earthquake along the Masbate fault on the island of Masbate (Besana et al., 2003). Moderately large historical earthquakes, such as those that occurred in 1875 $\left(M_{\mathrm{s}}=5.2\right), 1879\left(M_{\mathrm{s}}=6.9\right)$ (Bautista and Oike, 2000), $1991\left(M_{\mathrm{s}}=5.8\right)$ (Domasig, 1991), and $1994\left(M_{\mathrm{s}}=6.2\right)$ (Lanuza et al., 1994), have been attributed to movements along the Leyte segment on Leyte island. The creeping movement of the fault, especially in the central part of the island, accounts for the relatively low seismicity in that area (Duquesnoy et al., 1994). In St. Bernard, Southern Leyte, the cumulative movement along the segment has formed a steep ridge, which is susceptible to landslides. Several villages are located along the base of the ridge as are productive agricultural lands; both have been affected by and are continuously exposed to landslide hazards. On a macroeconomic scale, ground shaking along the Leyte segment has been causing frequent disruptions to the power transmission system of the Tongonan Geothermal Field, the largest wet-steam geothermal field in the world and a major contributor to the country's energy pool, because it is situated along this fault.

\section{Physical Setting}

Guinsaugon $\left(10^{\circ} 18.5^{\prime} \mathrm{N} 125^{\circ} 17^{\prime} \mathrm{E}\right)$ is one of several villages in the municipality of St. Bernard, Southern Leyte Province and is located at the foot of a 30-km-long northnorthwest-trending mountain ridge known locally as Mt. Can-abag. This ridge is a surface expression of the active Leyte segment of the PFZ. Stretching $1200 \mathrm{~km}$ across the Philippine archipelago from Luzon island to Mindanao island, the left-lateral PFZ has slip rates that average from 


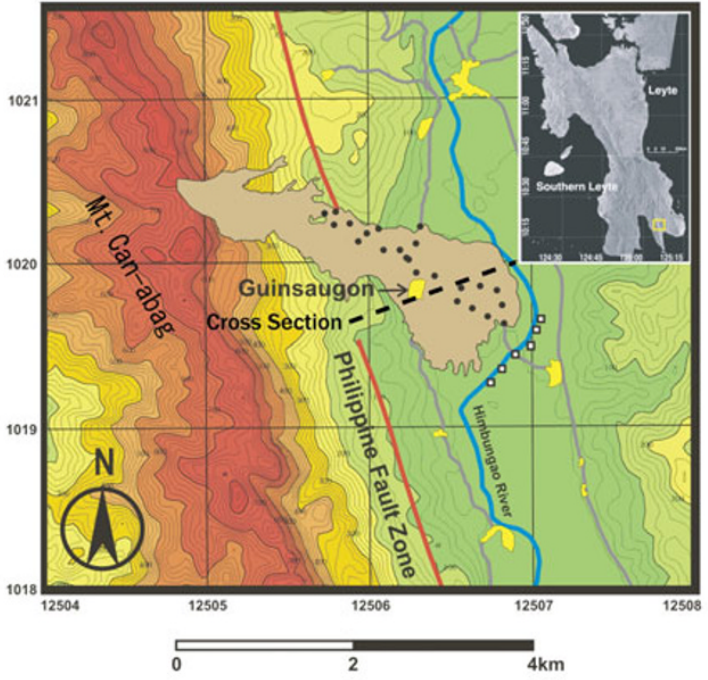

Fig. 1. Location map of gravity stations in the Guinsaugon landslide area on a topographic map generated from an SRTM-3 image (http://www2.jpl.nasa.gov/srtm/). The black circles and open squares show stations within and adjacent to the landslide area, respectively. The trace of the Philippine Fault Zone was determined from the SRTM-3 image and field mapping, while the outline of the landslide was obtained from GPS measurements (within the depositional and source areas) and a NASA image from ASTER data (http://earthobservatory.nasa.gov/Newsroom/NewImages/images.php3? img_id=17203). The yellow box in the inset (JERS-1 SAR image by ERSDAC) indicates the location of the surveyed area on Leyte island. The cross section $\left(\mathrm{N} 70^{\circ} \mathrm{E}\right.$ orientation) is used for a gravity analysis.

0.55 to $3.5 \mathrm{~cm} /$ year (Duquesnoy, 1997; Cole et al., 1989).

Local lithologies comprising Mt. Can-abag are generally sedimentary and igneous in nature. Dolores Formation andesitic volcaniclastic rocks dating from the late Pliocene to Pleistocene underlie the ridge and are capped by coralline limestone (JICA-MMAJ, 1990). The crown area of the 17 February 2006 landslide is composed of southwest-dipping volcaniclastic rocks consisting of breccias, sandstones, siltstones, and mudstones, all of which have been deposited in a transitional to shallow marine environment (Catane et al., 2006). Evidence of prehistoric landslides is inferred from the hummocky topography of the basal slopes of the ridge. The alluvial plain, where Guinsaugon and several other villages of St. Bernard are located, is underlain by recent river deposits of the Himbungao River. Highly sheared and serpentinized harzburgites exposed at the southern part of the ridge near Cabalian Bay serve as the basement lithology of Mt. Can-abag.

A prevailing La Niña phenomenon in early 2006 extended the season of pronounced rainfall, which normally lasts from November to January, well into February. Between 1 and 16 February 2006, $751 \mathrm{~mm}$ of cumulative rainfall, equivalent to 2.65-fold the average rainfall for February, was recorded. The peak maximum rainfall daily values of 131 and $171 \mathrm{~mm}$ were recorded on during 10-12 February, while very minimal rain was recorded on the day of the landslide itself (PAGASA, 2006). These values were recorded by a rain gauge stationed $7 \mathrm{~km}$ west of Guinsaugon, on the leeward side of the ridge. Because of orographic effects, this side most probably received lesser

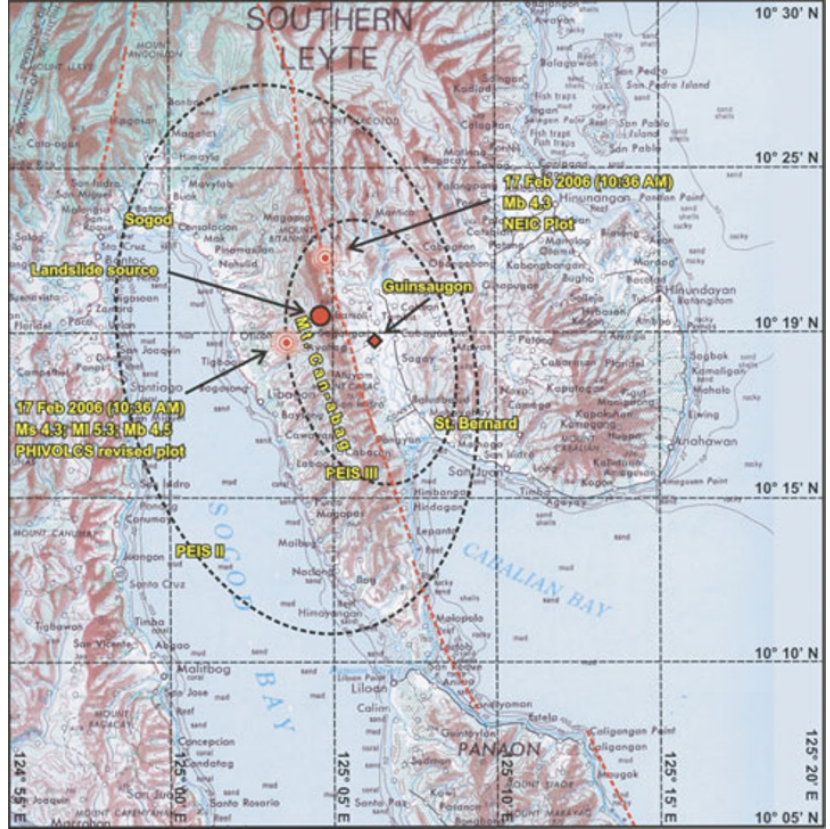

Fig. 2. Earthquake location and intensity map. The Philippine Institute of Volcanology and Seismology (PHIVOLCS) Earthquake Intensity Scale (PEIS) score was based on field interviews of residents in St. Bernard and adjacent municipalities as far as Sogod. The uninhabited and inaccessible northwest quadrant of the isoseismal map was inferred (modified from Daag et al., 2006)

amounts of precipitation relative to the slope adjacent to Guinsaugon.

\section{Chronology of the Landslide Event}

Residents of Guinsaugon describe several events that occurred in the vicinity prior to the huge landslide that buried their village. According to them, earthquake swarms from 1986-1988 caused minor soil falls from the source area. Small but frequent landslides also caused the exposure of the bedrock in the source area of the huge landslide. Witnesses had also observed several minor events before 17 February, such as the occurrence of small rock falls a few days before the major landslide and the distinct siltation of a stream leading to Guinsaugon one day before the catastrophic event. Catane et al. (2006) interpreted these minor events as possible precursors to the huge landslide of 17 February 2006.

Catane et al. (2006) chronicled the events that transpired prior to and during the catastrophic landslide based on eyewitness accounts of survivors and residents from nearby villages. At 6:07 A.M. (local time) on 17 February 2006, a mild earthquake was felt in Guinsaugon and the surrounding villages (Fig. 2). A stronger earthquake $\left(M_{\mathrm{s}}=4.3 ; M_{\mathrm{b}}=4.5\right)$, with an epicenter $\left(10.31^{\circ} \mathrm{N} 124.06^{\circ} \mathrm{E}\right)$ located $5 \mathrm{~km}$ west of Guinsaugon (Daag et al., 2006), at a depth of $6 \mathrm{~km}$ (data available at: http://www.phivolcs.dost.gov.ph/EQLatest.html), shook the area at 10:36 A.M.. The National Earthquake Information Center of the United States Geological Survey (USGS-NEIC), recorded the same earthquake $\left(M_{\mathrm{b}}=4.3\right)$ at $10: 36$ with an epicenter of $10.37^{\circ} \mathrm{N}$ $125.08^{\circ} \mathrm{E}$ and a focus of $35 \mathrm{~km}$ (data available at: 
(a)

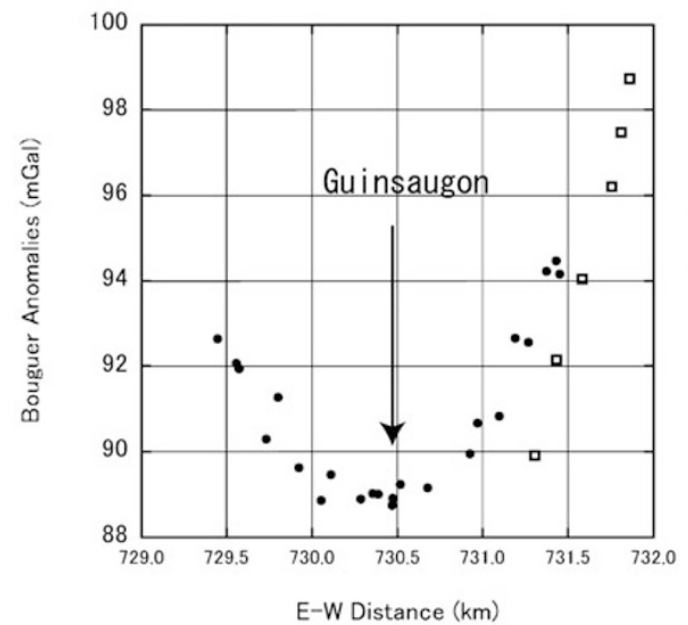

(b)

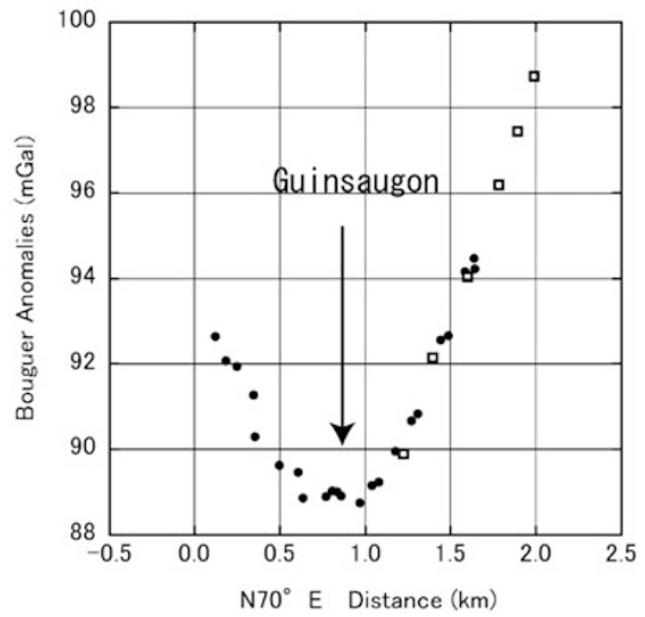

Fig. 3. Profiles of Bouguer anomalies in the $\mathrm{N} 90^{\circ} \mathrm{E}$ (a) and $\mathrm{N} 60^{\circ} \mathrm{E}$ (b) orientations. The assumed mass density is $2.3 \mathrm{~g} / \mathrm{cm}^{3}$. Symbols are the same as in Fig. 1. The relative position of Guinsaugon is indicated.

http://neic.usgs.gov/neis/epic/epic_rect.html). The intensity of the earthquake was measured at II-III on the Philippine Institute of Volcanology and Seismology (PHIVOLCS) Earthquake Intensity Scale (PEIS) (Daag et al., 2006) (IIIIV on the Rossi-Forel Scale; Catane et al., 2006). The USGS-NEIC and PHIVOLCS recorded these earthquakes, apparently of tectonic origin, on the basis of their foci. At almost the same time (10:37 A.M.), an earthquake in Guinsaugon was recorded by the seismographs of the F-net (Full Range Seismograph Network of Japan) (data available at: http://www.eri.u-tokyo.ac.jp/sachu/Seismo). The seismic data were processed through the 20- to 50-s. bandpass filter, and the extracted Rayleigh waves were attributed to the Guinsaugon landslide. Given these three sources of seismic data and interpretations, the earthquake could be of tectonic origin or generated by the landslide itself (Suwa, 2006). Near-source and distal records of the earthquakes have yet to be compared and analyzed to clarify the origin of the earthquake.

The 10:36 A.M. earthquake was followed by the successive detachment of three massive blocks from the slope face of Mt. Can-abag, which subsequently buried Guinsaugon. Witnesses claimed that the entire event lasted for about $5 \mathrm{~min}$. The landslide traveled $4.1 \mathrm{~km}$ from the source and covered $3.2 \mathrm{~km}^{2}$ with about $14-17 \mathrm{Mm}^{3}$ of debris. The maximum landslide velocity was estimated to be 120$130 \mathrm{~m} / \mathrm{s}$ based on the potential-kinetic energy relationship. There were a total of 139 confirmed deaths, while 980 individuals still remain unaccounted for.

The effect of saturation due to the excessive rainfall preceding the landslide has been examined by Zarco et al. (2007). Limit equilibrium analysis has revealed that in a wedge failure, a pore pressure of 258-306 KPa resulted in a sudden drop in the factor of safety to slightly below 1.0, which is the critical limit for stability This analysis is based on the unconfined compression values (UCS $=17.9-$ 23.0 MPa), a seepage height of $180 \mathrm{~m}$ determined from field measurements, and the assumption that the earthquake forces are pseudostatic.

\section{Gravity Survey Method}

A Lacoste and Romberg gravimeter (G-911) was used to make measurements at 29 gravity stations established in and around the Guinsaugon landslide from 21 to 26 April 2006 (Fig. 1). The FastStatic method using Trimble LS4600 and 4000SSi GPS receivers was applied to determine the relative location of the gravity stations from a base station established in the town center of St. Bernard.

Bouguer anomalies were calculated with standard corrections (GSJ Gravity Survey Group, 1989) for free-air, Bouguer, terrain and atmospheric, and removal of normal gravity, in accordance with the Geodetic Reference System 1980 (GRS, 1980). Terrain corrections were conducted within a range of $60 \mathrm{~km}$ using the mesh terrain data SRTM3.

\section{Results and Interpretation}

Figure 3 shows the profiles of Bouguer anomalies in the Guinsaugon landslide with an assumed mass density of $2.3 \mathrm{Mg} \mathrm{m}^{-3}\left(\mathrm{~g} / \mathrm{cm}^{3}\right)$. The source area of the landslide consists of Late Pliocene to Pleistocene andesitic volcaniclastic rocks; therefore, the mass density used in the gravity data analysis is the average of Tertiary volcanic sedimentary rocks from the Physical Property Database of Rocks of Japan (Murata et al., 1991; Suda et al., 1991). A lowgravity anomaly was detected at Guinsaugon, with an amplitude of $10 \mathrm{mGal}$. The valley in which Guinsaugon is situated is bounded by steep horizontal gradients of gravity anomalies. The gravity data can be divided into two groups, as shown in Figs. 1 and 3; that obtained within and adjacent to the landslide area are indicated by filled circles and open squares, respectively. In order to show a two-dimensional (2-D) effect, the coordinate system was rotated counterclockwise by $20^{\circ}$. When this rotation is applied, the data points merge into one group and are connected smoothly, as shown in Fig. 3(b).

The presence of the low-gravity anomaly suggests that the basement beneath Guinsaugon is deep-seated to a depth of a few kilometers, the upper layer of which is filled with 

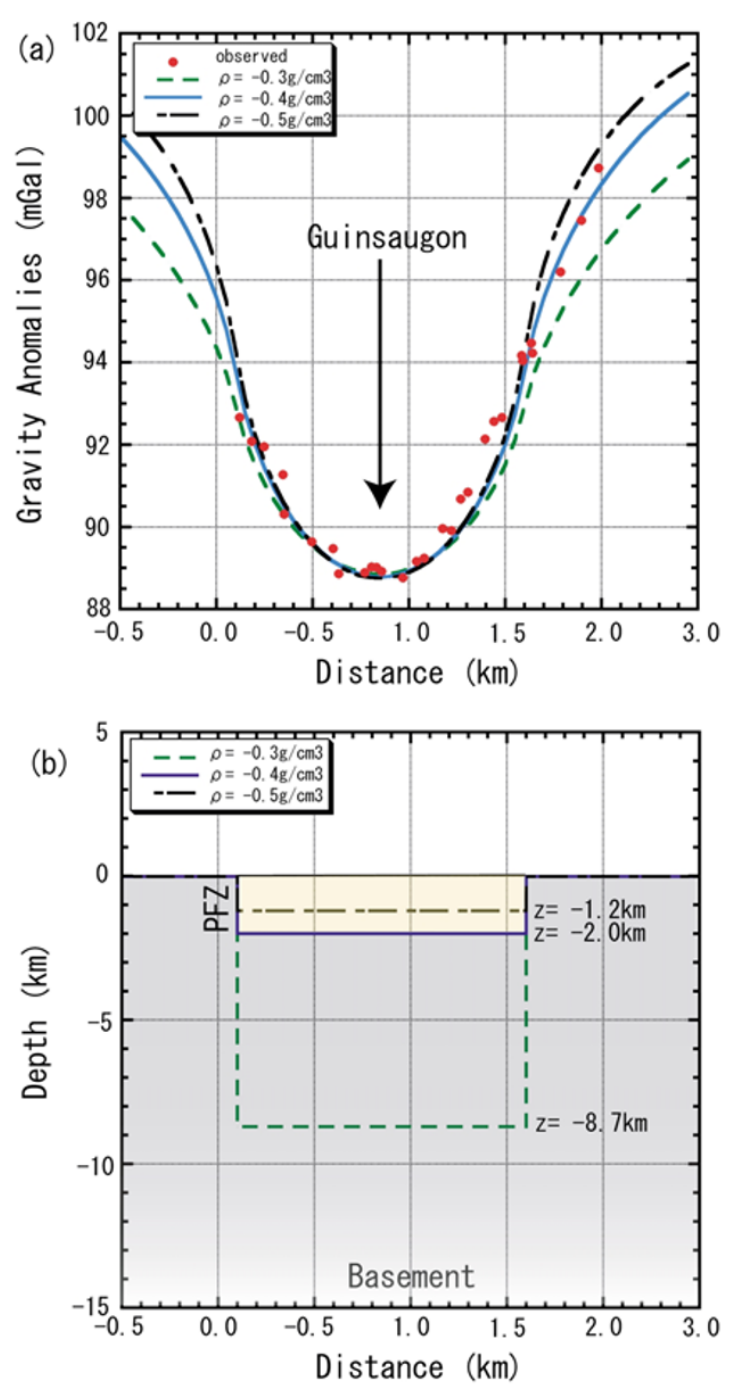

Fig. 4. Model calculations. (a) Observed and calculated gravity anomalies. Red dots represent observed gravity anomalies in Guinsaugon. Dotted, solid, and dashed curves show gravity anomalies caused by the graben with homogeneous density contrasts of $-0.3,-0.4$, and $-0.5 \mathrm{~g} / \mathrm{cm}^{3}$. The relative position of Guinsaugon is indicated. (b) Graben models of the subsurface in Guinsaugon.

low-density and soft sediments corresponding to the alluvial plain.

The density contrast between the sediments and the basement is an essential parameter when interpreting subsurface structures. In the absence of borehole data from the Guinsaugon landslide area, we assumed several density contrasts and subsequently constructed gravity basement models for calculated values to fit the observed anomalies. We obtained gravity anomaly profiles for homogeneous models with various density contrasts $\left(-0.3,-0.4,-0.5 \mathrm{~g} / \mathrm{cm}^{3}\right)$ using 2-D modeling (Talwani et al., 1959) (Fig. 4(a)). The generated subsurface models are shown in Fig. 4(b), where the volcaniclastic bedrocks are regarded as the gravity basement. These results show that there is a narrow graben filled with low-density sediments and that the west boundary of the basin corresponds to the PFZ. The depth of the basin is estimated to be $8.7,2$, and $1.2 \mathrm{~km}$ for density contrasts of $-0.3,-0.4$, and $-0.5 \mathrm{~g} / \mathrm{cm}^{3}$, respectively. The rootmeaning-squares (RMS) between the calculated and ob-

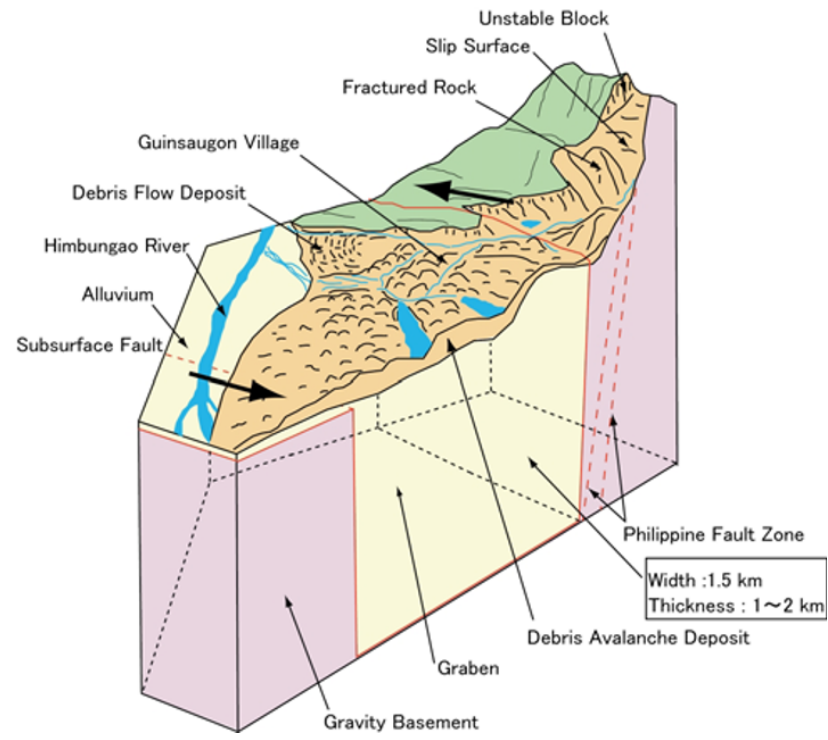

Fig. 5. Block diagram showing features of the landslide and the subsurface fault structure as seen from northeast direction (modified from Catane et al., 2006).

served gravity anomalies are $0.163,0.096$, and $0.115 \mathrm{mGal}$ for density contrasts of $-0.3,-0.4$, and $-0.5 \mathrm{~g} / \mathrm{cm}^{3}$, respectively. Thus, the density contrast of $-0.4 \mathrm{~g} / \mathrm{cm}^{3}$ supports a model of a graben with a $1.5-\mathrm{km}$ width and a $2-\mathrm{km}$ depth. Although the motion along PFZ is dominantly left lateral, the results of the gravity survey revealed a significant vertical displacement of the fault in the Guinsaugon area. This section of the fault could be interpreted as a pullapart basin.

Figure 5 shows the relationship between the landslide surface features and the subsurface fault structure. Field observations by Catane et al. (2006) confirmed the presence of an active fault-related zone of highly fractured and sheared materials from the top of the ridge down to its base. These structures are important preparatory factors for the landslide. Thus, the presence of a deep-seated fault at the foot of the steep slopes and the soft sediments in the narrow basin might be important factors for the analysis of the trigger and failure mechanisms of the landslide. The earthquake $\left(M_{\mathrm{s}}=4.3\right)$ that immediately preceded the landslide might be of significance as a landslide trigger. In the distribution map of seismic intensities of this earthquake, Guinsaugon has experienced the maximum seismic intensity (Fig. 2). Material amplification due to the presence of thick soft sediments beneath Guinsaugon, as shown in the subsurface structure model, may explain the stronger intensity of the earthquake despite its relatively low magnitude.

\section{Conclusions}

Our gravity analysis has revealed the subsurface structure of the PFZ in the Guinsaugon landslide area. We have shown that a narrow basin is filled with low-density and soft sediments, the thickness of which is about $2 \mathrm{~km}$. The two possible triggers of the landslide are earthquakes and increased pore pressure attributable to slope saturation prior to the landslide. The deep subsurface structure is the result of long-term, vertical and horizontal movements of 
the earth's crust along the PFZ, which has resulted in the steep slopes and highly fractured rocks of Mt. Can-abag. The combined effects of saturation and possible earthquake events may have contributed to the slope's instability. More geophysical data and analyses are needed to understand the anatomy of the fault and trigger mechanisms of the landslide.

Acknowledgments. We would like to acknowledge the technical support of our colleagues in the University of the Philippines (UP)-National Institute of Geological Sciences, UP-Department of Geodetic Engineering, UP-Department of Engineering Science and Dr. M. Komazawa of the Geological Survey of Japan, National Institute of Advanced Industrial Science and Technology. We are grateful to Ms. Tita Capili and Tanya Albino for their logistical support during our survey in St. Bernard, Southern Leyte. Critical reviews by A. Yamamoto and G. Besana-Ostman helped improve the manuscript.

\section{References}

Bautista, M. L. P. and K. Oike, Estimation of the magnitudes and epicenters of Philippine historical earthquakes, Tectonophysics, 317, 137-169, 2000.

Besana, G. M. and M. Ando, The central Philippine Fault Zone: location of great earthquakes, slow events, and creep activity, Earth Planets Space, 57, 987-994, 2005

Besana, G. M., J. A. Daligdig, N. M. Tungol, M. I. T. Abigania, B. Santos, B. J. T. Punongbayan, H. Penarubia, R. R. Maximo, L. Torrevillas, R. Dela Cruz, K. I. Papiona, and R. Lumbang, The Final Report of the 2003 Masbate Quake, PHIVOLCS Open File Report, pp. 1-30, 2003.

Catane, S. G., H. B. Cabria, C. P. Jr. Tomarong, R. M. Jr. Saturay, M. A. H. Zarco, and W. C. Pioquinto, Catastrophic rockslide-debris avalanche at St. Bernard, Southern Leyte, Philippines, Landslides, SpringerLink, doi:10.1007/s10346-006-0050-3, 2006.

Cole, J., R. McCabe, T. Moriarty, J. A. Malicse, F. G. Delfin, H. Tebar, and H. P. Ferrer, A preliminary Neogene paleomagnetic data set from Leyte and its relation to motion on the Philippine Fault, Tectonophysics, 168, 205-221, 1989.

Daag, A. S., O. Molina, D. Buena, and E. Gumabon, Deterministic modeling of rain- and earthquake-induced landslides in mountainous environments transected by an active fault, presented at Caravan Seminar on Geospatial Technologies for Disaster Mitigation: Philippines Perspective, Philippine Institute of Volcanology and Seismology, Makati City, Philippines, 27 November 2006, 2006.

Domasig, W. F., Report on the ground investigation of reported landslides and ground fissures and other earthquake-related damages in Cabalian-St. Bernard area in Southern Leyte, memorandum report, 6 p., Mines \& Geosciences Development Service, 1991.

Duquesnoy, T. H., Contribution de la geodesie a l'etude de grands decrochements actifs associes a des zones de subduction a convergence oblique, These de doceur en science, University of Paris-XI, Orsay, 1997.

Duquesnoy, T. H., E. Barrier, M. Kasser, M. Aurelio, R. Gaulon, R. S. Punongbayan, C. Rangin, and the French-Philippine Cooperation Team, Detection of creep along the Philippine Fault: first results of geodetic measurements on Leyte island, central Philippines, Geophys. Res. Lett., 21(11), 975-978, 1994.

Endo, H., S. Watanabe, M. Makino, Y. Murata, K. Watanabe, and A. Urabe, Damage caused by the 1995 Hyogoken-Nanbu Earthquake and concealed faults in the Hanshin area, Hyogo Pref. Japan, Quat. Res., 35, 165-178, 1996.

Ferguson, J. F., R. N. Felch, C. L. V. Aiken, J. S. Oldow, and H. Dockery, Models of the Bouguer gravity and geologic structure at Yucca Flat, Nevada, Geophysics, 53, 231-244, 1988.

GSJ Gravity Survey Group, On the standard procedure SPECG1988 for evaluating the correction of gravity at the Geological Survey of Japan, Bull. Geol. Surv. Jpn., 40, 601-611, 1989 (in Japanese with English abstract).

JICA-MMAJ, The mineral exploration-mineral deposits and tectonics of two contrasting geologic environments in the Republic of the Philippines, Consolidated report on Leyte, Dinagat and Surigao areas, Japan International Cooperation Agency-Metal Ming Agency of Japan, Japan, 1990.

Komazawa, M., Gravimetric analysis of Aso Volcano and its interpretation, J. Geodetic Soc. Jpn., 41, 17-45, 1995.

Lanuza, A. G., A. V. Chu, E. A. Mangao, D. S. Soneja, R. Sanez, and D. C. Garcia, Aftershocks observation of 05 July 1994 earthquake in Cabalian area, Southern Leyte, PHIVOLCS internal report, 35 p., Philippine Institute of Volcanology and Seismology, 1994.

Litinsky, V. A., Concept of effective density: key to gravity depth determinations for sedimentary basin, Geophysics, 54, 1474-1482, 1989.

Lukandu, A. I., S. Okuyama, and S. Takemoto, Gravity inversion modeling across fault/tectonic lines in the Central Ranges in Honshu, Japan, $J$. Geol. Soc. Jpn., 49, 73-82, 2003.

Makino, M., An improved method for two-dimensional gravity analysis by using logarithmic functions: an application to the Kobe area, ButsuriTansa, 50, 123-131, 1997 (in Japanese with English abstract).

Makino, M. and H. Endo, Gravity survey around the area of the Hariharagawa debris flow at Izumi, Kagoshima Prefecture, Butsuri-Tansa, 52, 153-160, 1999 (in Japanese with English abstract).

Murata, Y., Y. Suda, and T. Kikuchi, Rock physical properties of Japandensity, magnetism, P-wave velocity, porosity, thermal conductivity, Open File Report 276, 302 p., Geological Survey of Japan, 1991 (in Japanese).

PAGASA, Rainfall data from Otikon, Libagon, Southern Leyte, Philippine Atmospheric Geophysical and Astronomical Services Agency (PAGASA), Philippines, 2006.

Suda, Y., Y. Murata, T. Kikuchi, and N. Hanaoka, Physical properties database of rocks (PROCK), Open File Report 155, 231 p., Geological Survey of Japan, 1991 (in Japanese).

Suwa, H., Catastrophe by the 17 February 2006 Southern Leyte landslide in Phillipine, J. Jpn. Soc. Natural Disaster Sci., 25, 83-97, 2006 (in Japanese with English abstract).

Talwani, M., J. L. Worzel, and M. Landisman, Rapid gravity computations for two-dimensional bodies with application to the Mendocino submarine fracture zone, J. Geophys. Res., 64, 49-59, 1959.

Williams, H. A., J. Cassidy, C. A. Locke, and K. B. Sporli, Delineation of a large ultramafic massif embedded within a major SW Pacific suture using gravity methods, Tectonophysics, 424, 119-133, 2006.

Yokoyama, I. and S. Ohkawa, The subsurface structure of the Aira Caldera and its vicinity in the southern Kyushu, Japan, J. Volcanol. Geotherm. Res., 30, 253-282, 1986.

Zarco, M. A. H., S. G. Catane, H. B. Cabria, R. M. Saturay, Jr., and A. S. Mirasol-Robert, Failure mechanism of a massive landslide: analysis of the 17 February 2006 Guinsaugon rockslide-debris avalanche, Philippines, Proceedings of the $4^{\text {th }}$ Civil Engineering Conference in the Asian Region, Taipei, Taiwan, June 26-28, 2007.

M. Makino (e-mail: m-makino@aist.go.jp), A. A. Mandanas, and S. G. Catane 